\title{
Changes in Photosynthesis Could Provide Important Insight into the Interaction between Wheat and Fungal Pathogens
}

\author{
Huai Yang and Peigao Luo *(D)
}

check for updates

Citation: Yang, H.; Luo, P. Changes in Photosynthesis Could Provide Important Insight into the Interaction between Wheat and Fungal Pathogens. Int. J. Mol. Sci. 2021, 22, 8865. https://doi.org/10.3390/ ijms22168865

Academic Editor: Vitaliy Borisov

Received: 24 July 2021

Accepted: 13 August 2021

Published: 18 August 2021

Publisher's Note: MDPI stays neutral with regard to jurisdictional claims in published maps and institutional affiliations.

Copyright: (C) 2021 by the authors Licensee MDPI, Basel, Switzerland. This article is an open access article distributed under the terms and conditions of the Creative Commons Attribution (CC BY) license (https:/ / creativecommons.org/licenses/by/ $4.0 /)$.
Provincial Key Laboratory for Plant Genetics and Breeding, College of Agronomy, Sichuan Agricultural University, Chengdu 611130, China; yanghuai202103@163.com

* Correspondence: lpglab@sicau.edu.cn

\begin{abstract}
Photosynthesis is a universal process for plant survival, and immune defense is also a key process in adapting to the growth environment. Various studies have indicated that these two processes are interconnected in a complex network. Photosynthesis can influence signaling pathways and provide both materials and energy for immune defense, while the immune defense process can also have feedback effects on photosynthesis. Pathogen infection inevitably leads to changes in photosynthesis parameters, including Pn, Gs, and Ci; biochemical materials such as SOD and CAT; signaling molecules such as $\mathrm{H}_{2} \mathrm{O}_{2}$ and hormones; and the expression of genes involved in photosynthesis. Some researchers have found that changes in photosynthesis activity are related to the resistance level of the host, the duration after infection, and the infection position (photosynthetic source or sink). Interactions between wheat and the main fungal pathogens, such as Puccinia striiformis, Blumeria graminis, and Fusarium graminearum, constitute an ideal study system to elucidate the relationship between changes in host photosynthesis and resistance levels, based on the accessibility of methods for artificially controlling infection and detecting changes in photosynthesis, the presence of multiple pathogens infecting different positions, and the abundance of host materials with various resistance levels. This review is written only from the perspective of plant pathologists, and after providing an overview of the available data, we generally found that changes in photosynthesis in the early stage of pathogen infection could be a causal factor influencing acquired resistance, while those in the late stage could be the result of resistance formation.
\end{abstract}

Keywords: photosynthesis; wheat diseases; immune defense; ROS; gene expression

\section{Introduction}

Photosynthesis is a universal process in the plant kingdom that occurs in various green organs, such as leaves [1], young stems [2], green fruits [3], and ears before maturity [4], providing a material basis and energy supply for multiple physiological metabolic processes in plants [5]. Plant organs that can perform photosynthesis are considered photosynthetic source organs, which mainly include the leaves of plants, while the storage organs of the organic matter synthesized by photosynthesis represent photosynthetic sink organs, which include mainly stalks, roots, and fruits [6]. At different growth and development stages, the photosynthetic sources and sinks can change accordingly. For instance, when plants are in the seedling stage, leaves and stems act as both sources and sinks of photosynthesis because photosynthates are supplied for their own growth and development. Photosynthesis is disrupted by a variety of complex factors, including abiotic stresses caused by water [7], temperature [8], light [9], and mechanical damage [10] and biological stresses caused by insects and pathogens [11,12]. In contrast, photosynthetic changes during this process may be related to responses to these factors.

Photosynthesis is sensitive to abiotic stress. Lack of water can limit photosynthesis efficiency due to thylakoid membrane damage and reduced chlorophyll contents [13]. Both high and low temperatures inhibit the activities of photosynthesis-related enzymes 
and membrane-associated electron carriers, thus further reducing the rate of photosynthesis $[14,15]$. Light intensities higher than the light saturation point of photosynthesis can cause photoinhibition of photosystem II (PSII) [9], and limited irradiance also directly leads to a decline in the photosynthesis rate [16]. In addition, complex photosynthetic changes can also be caused by the invasion of various insects and pathogens. For example, the photosynthesis rate of rice leaves is inhibited by Nilaparvata lugens infestation, especially in the lower part of the leaves [17], and the net photosynthesis rate (Pn) and related parameters of susceptible tomato leaves are affected by inoculation with Fusarium oxysporum $\mathrm{f}$. sp. lycopersici or Verticillium albo-atrum [18]. The photosynthesis capacity of maize leaves is also inhibited by infection with Colletotrichum musae and Fusarium moniliforme, and the inhibition is accompanied by a sharp decrease in chlorophyll content [19]. Changes in photosynthesis in response to changes in environmental conditions constitute a traditional and interesting topic for scientists in the field of photosynthesis. However, the objective of this review is to underscore photosynthetic changes during pathogenesis from the standpoint of pathologists.

It is well known that most pathogen invasions lead to a decline in the photosynthesis rate of the host $[20,21]$. However, various authors carefully monitored the photosynthetic changes during pathogen infection in a host and detected a very significant phenomenon: in the early stages of infection by a large number of different pathogens, the photosynthesis capacity of the host always decreases [22-25]. For example, photosynthesis in both resistant and susceptible barley decreased after inoculation with powdery mildew, and moreover, the decrease in photosynthesis in the resistant plants was larger than that in the susceptible plants [22]. Similar decreases were also observed in interactions between tobacco and Phytophthora nicotianae [23] and between Arabidopsis and Pseudomonas syringae [26]. These findings indicate that the difference in the degree of photosynthetic changes in the early stages of infection could conversely be an indicator of the resistance level.

\section{Wheat and Its Fungal Pathogens Constitute Ideal Pathogen Systems for Studying the Role of Photosynthesis in the Process of Resistance Development}

\subsection{Characteristics of the Three Major Fungal Diseases of Wheat}

Wheat is one of the most important crop species and has been a staple food of humans for thousands of years worldwide [27]. The growth period of wheat is longer than that of other food crop species such as maize and rice, making wheat more susceptible to various pathogens and diseases during its growth and development [28]. Among these diseases, the wheat powdery mildew caused by the obligate biotrophic fungus Blumeria graminis f. sp. tritici (Bgt), stripe rust caused by the biotrophic parasite Puccinia striiformis f. sp. tritici (Pst), and Fusarium head blight (FHB), which is caused mainly by Fusarium graminearum species, are the three most severe diseases affecting both yield and quality [29,30]. The basic characteristics of the three diseases are listed in Table 1 . Wheat powdery mildew is an epidemic disease worldwide, especially in regions such as southwestern China, whose environment is temperate and rainy during the wheat growing season [31]. Furthermore, powdery mildew can occur throughout the whole growth period of wheat, and the optimal temperature for its occurrence is $15-20^{\circ} \mathrm{C}$ [32]. For the infected position, Bgt pathogens infect mainly the leaves and sometimes also infect green awns, glumes, and stalks [33]. These organs differ largely in the position of the plant, but they are usually considered photosynthetic source organs at the developmental stage because of their strong photosynthetic competence [34]. Therefore, wheat powdery mildew is a typical source disease from the perspective of photosynthetic function. Wheat stripe rust is also one of the most threatening diseases in wheat production worldwide [35], especially in temperate climates. Stripe rust can occur during the whole growth period from seedling emergence to maturity, and the optimum temperature for its occurrence is $13-16{ }^{\circ} \mathrm{C}[36,37]$. The tissue specificity of stripe rust is stronger than that of wheat powdery mildew, which mainly parasitizes leaves, the main source of wheat photosynthesis, and seldom occurs in wheat stems and glumes [38]. Therefore, wheat stripe rust is also a typical source disease from the perspective of source-sink relationships. 
Table 1. Characteristics of the three major fungal diseases of wheat.

\begin{tabular}{cccccc}
\hline $\begin{array}{c}\text { Major Diseases in } \\
\text { Wheat }\end{array}$ & Pathogen & $\begin{array}{c}\text { Position of } \\
\text { Infection }\end{array}$ & Infection Period & $\begin{array}{c}\text { Optimal } \\
\text { Temperature }\end{array}$ & $\begin{array}{c}\text { Classification of } \\
\text { Diseases }\end{array}$ \\
\hline Powdery mildew & $\begin{array}{c}\text { Blumeria graminis } \mathrm{f} . \\
\text { sp. tritici }(B g t)\end{array}$ & leaf & whole growth period & $15-20{ }^{\circ} \mathrm{C}[32]$ & source disease \\
\hline Stripe rust & $\begin{array}{c}\text { Puccinia striiformis } \\
\text { f. sp. tritici (Pst) }\end{array}$ & leaf & whole growth period & $13-16{ }^{\circ} \mathrm{C}[36,37]$ & source disease \\
\hline Fusarium head blight & $\begin{array}{c}\text { Fusarium } \\
\text { graminearum } \\
\text { species complex }\end{array}$ & ear & adult stage & $20-25^{\circ} \mathrm{C}[39]$ & sink disease \\
\hline
\end{tabular}

It is well known that the occurrence of FHB in wheat is extremely harmful to the quality of wheat because the causal agent produces the mycotoxin deoxynivalenol (DON), which is poisonous to both humans and animals [40]. At the same time, FHB can also cause great loss of wheat yield, especially under the environment conditions suitable for F. graminearum growth and breeding [41,42]. F. graminearum infects mainly the ears of wheat at the adult stage, and they are generally considered sink organs due to their role as a storage location for photosynthates in wheat. Therefore, in contrast to wheat powdery mildew and stripe rust, FHB is a typical sink disease. Measurements of photosynthesis parameters of FHBresistant/susceptible sister-line wheat after inoculation with F. graminearum showed that the photosynthesis rate of susceptible wheat leaves did not change significantly, while the photosynthesis rate of resistant wheat leaves decreased significantly in the early stage after pathogen infection, but the resistant genotype produced a larger yield than the susceptible genotypes did [43]. This indicates that the decrease in photosynthesis rate could play a key role in inducing systemic resistance to maintain the ultimate yield.

\subsection{Wheat and Its Tissue-Specific Diseases Constitute an Ideal System}

The mechanism through which both stripe rust and powdery mildew cause yield losses could be different from that of FHB because of the difference in the infection positions. A variety of wheat leaf diseases can reduce the amount of green leaf area, resulting in a decrease in chlorophyll contents in the infected parts [44], which directly reduces the photosynthesis capacity and both the synthesis and the accumulation of organic matter in photosynthetic source organs, leading to a decline in wheat yield [45]. For instance, the chloroplast envelope of wheat mesophyll cells is disrupted after infection with Bgt, and the thylakoid becomes enlarged [45]. The effector protein of wheat stripe rust fungus can inhibit chloroplast function [46], and Pst infection can also reduce the chlorophyll content in wheat leaves [24]. However, there may be several reasons for wheat yield loss caused by FHB. Studies have indicated that damaged photosynthetic sink organs may inhibit photosynthesis at the source via feedback mechanisms, which could be the important reason to explain the yield loss caused by FHB $[43,47]$.

In addition, a few reports have indicated that photosynthesis may be involved in wheat immune defense responses to fungal pathogens and may influence resistance formation because changes in photosynthesis may provide an important signal for maintaining source- sink balance during interactions between wheat and pathogens [12,48]. However, there are few relevant research reports on the role of photosynthesis in influencing the formation of wheat resistance, and those studies have focused mainly on photosynthetic changes after inoculation with pathogens, so knowledge about the influence of photosynthesis is very fragmented or not systematic [49]. Both wheat powdery mildew and stripe rust are source organ diseases, and FHB is a sink organ disease. Hence, wheat and its fungal pathogens constitute an ideal pathogen system for exploring the role of photosynthesis in the development of wheat resistance. 


\section{Relationships between Yield and Photosynthetic Changes Caused by Pathogen Infection in Wheat}

\subsection{Effects of Photosynthetic Changes on Wheat Yield}

Decreases in wheat yield caused by pathogen infection have always been a focus of wheat breeders and physiologists [50]. A large number of studies have reported adverse effects of wheat leaf diseases (such as powdery mildew and stripe rust) and ear diseases (such as FHB) on wheat yield [51,52]. Infection of wheat powdery mildew at the seedling stage can affect the growth and development of wheat plants [53] and can further lead to a decrease in grain filling and grain weight at the adult stage [33]. Wheat stripe rust infection not only can reduce the number of tillers at the tillering stage [54] but also can significantly reduce the grain number per spike and 1000-grain weight at the adult stage [55]. Wheat stripe rust and powdery mildew have very similar effects on wheat yield because they both directly act on the source organs of wheat photosynthesis and cause wheat yield losses through long-term inhibition of photosynthesis in wheat leaves $[52,56,57]$. In addition, both Bgt and Pst are parasitic fungi that rely on host metabolism to provide carbohydrates, amino acids, and inorganic nutrients [58,59]. The growth and reproduction of a large number of pathogens directly consume nutrients in photosynthetic source organs, further reducing wheat yields [58].

The production of the mycotoxin DON in diseased wheat ears is the main negative effect caused by FHB but could also lead to severe yield losses due to a damaged photosynthetic sink and a disrupted source-sink balance $[40,43]$. It has been reported that FHB can cause $10-70 \%$ yield losses in years in which epidemics occur [45]. Unfortunately, how the damage of photosynthetic sink organs causes the changes of photosynthetic source organs remains to be further explored. It has been reported that the activity of photosynthesisrelated enzymes and the expression of associated gene transcripts are modified by sink demand [60]. Stomatal closure is a plant's first line of defense against pathogens [61]. Recent studies have suggested that the reduced photosynthetic efficiency of susceptible wheat leaves is regulated by stomatal factors after the occurrence of FHB symptoms, while the Gs of resistant wheat leaves did not show a significant decrease under the same treatment $[43,50]$. These reports suggest that when pathogens attack the photosynthetic sinks of wheat, there is some kind of feedback regulatory mechanism that alters the balance between photosynthetic sources and sinks by adjusting photosynthesis parameters.

\subsection{Association between Changes in Photosynthesis and Immune Defense in the Early Stages after Pathogen Infection}

In the past, plant defense responses and photosynthesis have been studied independently. With the mechanisms underlying plant photosynthesis and immune defense gradually becoming clear, it has been found that plant photosynthesis can provide materials and can serve as a signal transduction basis for plant immune defense [49,62], which indicates that plant photosynthesis and immune defense processes are interconnected [63]. A series of reports have shown that host photosynthesis usually declines in the early stages of invasion by various pathogens $[25,64-66]$, which may be involved in the immune response of the host. For instance, in incompatible reactions between tobacco and P. nicotianae, the photosynthetic electron transport chain in tobacco leaves is disrupted, and photosynthetic activity decreases with the accumulation of reactive oxygen species (ROS) just a few hours after inoculation [23]. Moreover, when interactions between Arabidopsis and P. syringae strains were analyzed, it was found that both virulent and avirulent strains of P. syringae could cause a decrease in photosynthesis in Arabidopsis leaves, and a decrease in photosynthesis was detected within only $3 \mathrm{~h}$ after pathogen inoculation during incompatible reactions [24]. Although the molecular mechanism underlying the decrease in photosynthesis caused by pathogen infection in the early stage remains unclear, recent studies on photosynthetic changes caused by various pathogens have provided several clues to help elucidate the role of photosynthetic changes in the defense response. 
Infection of wheat pathogenic fungi in the leaves and ears can cause a decrease in photosynthesis in wheat leaves. The decline in photosynthesis in the early stage of various fungal pathogens invasion in wheat are listed in Table 2. In incompatible reactions, the decrease in photosynthesis capacity of the host may be due to the material and energy needed for defense [67], while in compatible reactions, the decrease in photosynthesis capacity may be due to the damage caused by pathogen infection of the host $[68,69]$. Unlike the transcriptomic and photosynthetic changes in sister wheat lines after inoculation with Bgt., it was found that the inhibition of photosynthesis in resistant wheat paralleled the global downregulation of photosynthesis-related genes to actively regulate the immune response, but the decrease in photosynthesis in susceptible wheat lines is caused by stomatal closure and did not regulate the immune response [25]. The infection of wheat stripe rust also causes a phenomenon similar to that caused by powdery mildew. The Pn of the resistant cultivar CN19 carrying the gene Yr41 [70] and the susceptible cultivar Sy95-71 decreased significantly at $72 \mathrm{~h}$ after inoculation with Pst compared with no inoculation [24]. By exploring the resistance mechanism of wheat resistance genes, it was also found that, by inhibiting photosynthesis, the stripe rust resistance gene $Y r 36$ could provide broadspectrum resistance to $P_{s t}$ races in wheat at the adult stage [71]. Studies on the signals of photosynthetic changes caused by wheat leaf diseases have also suggested that the resistant genotypes of wheat could actively regulate photosynthetic changes to mediate specific immune defenses against the invasion of pathogens, albeit at a cost of greatly reduced photosynthesis capacity in the initial stage of pathogen infection [72]. Taken together, these results indicate that the changes in photosynthesis parameters in the early stage of stripe rust and powdery mildew infection in wheat were related to the development of resistance.

Table 2. Changes in photosynthesis and antioxidant enzyme activity in response to the three main fungal pathogens in wheat at the early stage of infection (within $72 \mathrm{~h}$ ).

\begin{tabular}{|c|c|c|c|c|c|c|c|c|}
\hline $\begin{array}{c}\text { Major Diseases } \\
\text { in Wheat }\end{array}$ & Parameter (Leaf) & $\begin{array}{c}\text { Wheat } \\
\text { Cultivar/Line }\end{array}$ & Resistance & $\mathbf{O h}$ & $12 \mathrm{~h}$ & $24 \mathrm{~h}$ & $48 \mathrm{~h}$ & $72 \mathrm{~h}$ \\
\hline \multirow[t]{6}{*}{ Powdery mildew } & $\operatorname{Pn}[25]$ & L658 & $\mathrm{R}$ & $\mathrm{CG}$ & $\searrow$ & $\nearrow$ & $\rightarrow$ & $\searrow$ \\
\hline & & L958 & S & $\mathrm{CG}$ & $\searrow$ & & $\rightarrow$ & \\
\hline & SOD [25] & L658 & $\mathrm{R}$ & $\mathrm{CG}$ & $\rightarrow$ & $\rightarrow$ & $\rightarrow$ & 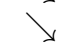 \\
\hline & & L958 & $S$ & $\mathrm{CG}$ & $\nearrow$ & $\rightarrow$ & $\searrow$ & \\
\hline & CAT [25] & L658 & $\mathrm{R}$ & $\mathrm{CG}$ & $\searrow$ & $\nearrow$ & $\searrow$ & \\
\hline & & L958 & S & $\mathrm{CG}$ & $\rightarrow$ & & $\searrow$ & \\
\hline \multirow[t]{4}{*}{ Stripe rust } & Pn [24] & CN19 & $\mathrm{R}$ & $\mathrm{CG}$ & - & - & - & $\searrow$ \\
\hline & & Sy95-71 & S & CG & - & - & - & $\searrow$ \\
\hline & $\operatorname{Pn}[73]$ & $\begin{array}{l}\text { psbo-A1 } \\
\text { Mutant }\end{array}$ & $\mathrm{R}$ & - & - & - & $\searrow$ & - \\
\hline & & Kronos & S & - & - & - & CG & - \\
\hline \multirow[t]{6}{*}{ Fusarium head blight } & Pn [74] & L693 & $\mathrm{R}$ & $\mathrm{CG}$ & - & $\searrow$ & $\rightarrow$ & $\rightarrow$ \\
\hline & & L661 & $S$ & $\mathrm{CG}$ & - & $\rightarrow$ & $\rightarrow$ & $\rightarrow$ \\
\hline & SOD [74] & L693 & $\mathrm{R}$ & $\mathrm{CG}$ & - & $\searrow$ & $\rightarrow$ & $\rightarrow$ \\
\hline & & L661 & S & $\mathrm{CG}$ & - & $\vec{\lambda}$ & $\rightarrow$ & $\rightarrow$ \\
\hline & CAT [74] & L693 & $\mathrm{R}$ & $\mathrm{CG}$ & - & $\nearrow$ & $\rightarrow$ & $\rightarrow$ \\
\hline & & L661 & S & CG & - & $\searrow$ & $\searrow$ & $\searrow$ \\
\hline
\end{tabular}

CP: control group; \: indicates that the current time has decreased significantly from the previous point in time; $\nearrow$ : indicates that current time has increased significantly from the previous point in time; $\rightarrow$ : indicates that current time had no significant change from the previous point in time; -: indicates that no available data were detected.

Interestingly, photosynthesis-related parameters in the ears and leaves of resistant and susceptible wheat were found to be significantly different after inoculation with F. graminearum [74]. The photosynthesis of wheat spikes increased at the early stage of inoculation in both resistant and susceptible plants, although the spikes were directly infected by F. graminearum; however, there was a larger increase in the ears and a larger decrease in the leaves in the resistant plants than in the susceptible plants [74]. Therefore, 
changes in the photosynthesis parameters of different genotypes of wheat may provide important insight into the mediation of immune defense responses to wheat sink diseases.

\section{ROS Produced by Photosynthesis Relay Compatibility or Incompatibility Signals}

Photosynthesis can regulate the immune defense response in many ways, the most important of which is by inducing the production of ROS and regulating changes in hormones $[12,48,67]$. ROS, including singlet oxygen $\left({ }^{1} \mathrm{O}^{2}\right)$, superoxide anion radicals $\left(\mathrm{O}^{2 \bullet-}\right)$, hydrogen peroxide $\left(\mathrm{H}_{2} \mathrm{O}_{2}\right)$, and hydroxyl radicals $(\bullet \mathrm{OH})$ are produced mainly during interactions between metabolic intermediates and oxygen during photosynthesis $[75,76]$. The concentration of ROS in plants is maintained usually at low levels due to rapid and precise regulation by various antioxidant enzymes, mainly catalase (CAT), superoxide dismutase (SOD), ascorbate peroxidase (APX), and peroxidase (POD) [76]. The metabolism of ROS has a dual role in plant growth and development. On the one hand, high concentration of ROS accumulation in plant cells can ultimately damage proteins, lipids, and nucleic acids and can even disrupt photosynthesis, and ROS are toxic to many cellular processes in plants [77-79]. On the other hand, a role for ROS in the immune defense has gradually been elucidated, indicating that ROS play a crucial role in plant immune defense [80]. The production of ROS is one of the earliest cellular reactions following pathogen recognition [81]. Many studies have revealed that low concentrations of ROS can activate the expression of defense-related genes and induce various defense responses [82], while a high accumulation of ROS can be used as a defense weapon to resist pathogen invasion [83]. In addition, ROS can regulate immune defense through interactions with plant hormones [84,85], and the synergistic effect of ROS and salicylic acid (SA) plays an important role in mediating the hypersensitive response (HR) $[86,87]$. In interactions between plants and pathogens, the ROS that accumulate are generated mainly by photosystem I (PSI) and PSII during photosynthesis [88]. Therefore, the changes in ROS caused by photosynthetic changes could be an important factor explaining why early photosynthesis is involved in the development of plant disease resistance, which ultimately results in compatibility or incompatibility between pathogens and hosts.

A large number of studies have suggested that the accumulation of ROS, particularly $\mathrm{H}_{2} \mathrm{O}_{2}$, constitutes an important signal that is transmitted and may determine the compatibility between pathogenic fungi and wheat in the early stage of infection $[69,73,89]$. For instance, transgenic experiments confirmed that, after being transferred to a resistance gene, the powdery mildew resistance of susceptible wheat variety Yangmai 158 was significantly improved at the seedling and mature stages and accumulated more ROS at the $B g t$ infection position [90]. The results indicate that ROS could improve the resistance of wheat to powdery mildew. By measuring the changes in ROS and photosynthesis in resistant/susceptible sister wheat lines after inoculation with $B g t$, Hu et al. [25] reported that two stages of $\mathrm{H}_{2} \mathrm{O}_{2}$ bursts occurred during the incompatible reaction process and that a single low-amplitude and transient $\mathrm{H}_{2} \mathrm{O}_{2}$ outbreak in susceptible wheat lines was not sufficient to induce the HR. In addition, ROS signaling plays a crucial role in the immune response to stripe rust caused by the parasitic fungus Pst. Overexpression of LSD-1-like zinc-finger protein ( $T a L O L)$, which actively regulates the ROS signaling pathway, can enhance resistance to stripe rust by inducing the production and accumulation of ROS and cell death, while silencing TaLOL2 increases sensitivity to avirulent races of Pst and reduces ROS production in wheat [73]. These results indicate that the accumulation of ROS acts as an important signal of immune defense in wheat leaf diseases caused by parasitic fungi.

FHB resistance is an extremely complex trait that is controlled by multiple quantitative trait loci (QTLs) and includes the additive effect of several genes [91]. Wheat resistance to FHB consists of two main types: resistance to the initial infection (type I resistance) and resistance to the spread of the disease within the wheat head (type II resistance) [92]. F. graminearum, the causal agent of wheat FHB, is a hemibiotroph that can absorb nutrients from dead tissues, so the HR mediated by the accumulation of ROS may not easily effectively resist FHB [93]. The results of some studies on the changes in ROS levels during 
FHB infection are consistent with our views. For instance, comparative transcriptome analysis suggested that ROS may accumulate in susceptible mutants of the wheat cultivar Wangshuibai after inoculation with $F$. graminearum but not in FHB-resistant cultivars of Wangshuibai [94]. Another example is the FHB-resistant line L693, which exhibits temporary infection symptoms due to insufficient accumulation of ROS after inoculation with F. graminearum, after which systemic acquired resistance (SAR) is induced in distal tissues via the SA pathway to resist pathogen invasion [74]. These results indicate that type II resistance to spreading within the wheat head mediated by the jasmonic acid (JA) or SA pathway may determine the compatibility between pathogens and wheat instead of mediating a strong immune defense response based on ROS at the site of parasitic fungal infection $[74,94,95]$. Therefore, it is difficult to determine the compatibility of $F$. graminearum with wheat by outbreak of ROS in the infected position, but ROS produced in a pathogeninfected position may play a role in signaling pathways because ROS are closely related to the SA pathway.

\section{Gene Expression Change Profiles Support the View That Photosynthesis Plays an Important Role in the Formation of Resistance}

The changes in photosynthesis parameters, ROS bursts, and POD activity during compatibility and incompatibility responses can reveal only superficial changes in the plant-mediated immune defense response. The gene expression change profiles in the interaction between pathogens and host can systematically reveal the changes of physiological metabolism and signaling molecules involved in immune defense during the formation of host resistance [96-98]. During pathogen invasion, the changes of host photosynthesis were associated with the expression of photosynthesis-related genes [99]. The expression of genes related to the regulation of ROS and plant hormone synthesis and catabolism can indicate the changes of ROS and hormone levels in the host [100]. For instance, some studies have indicated that the expression of photosynthesis-related genes is generally downregulated under biotic stress, which is conducive to the production of ROS [101,102], while the upregulated expression of genes involved in the synthesis of JA, SA, and ethylene (ET) can stimulate the hormone-mediated defense response [103]. In addition, the accumulation of $\mathrm{H}_{2} \mathrm{O}_{2}$ in chloroplasts can lead to an increase in the level of SA [104], which in turn inhibits $\mathrm{H}_{2} \mathrm{O}_{2}$-scavenging enzymes such as CAT and APX [105]. In the process of interaction between host and pathogen, ROS, antioxidant enzymes, plant hormones, and photosynthesis constitute a complex mutual regulation network, and it is difficult to explore the relationship between them only by measuring physiological and biochemical indicators $[106,107]$. Therefore, comparing the changes in photosynthesis-related genes during the occurrence of different types of fungal diseases in wheat is beneficial for understanding the molecular mechanism through which wheat mediates different types of immune defense processes.

5.1. Global Downregulation of Photosynthesis-Related Genes in Response to Many Wheat Diseases May Disrupt Photosynthesis and Promote ROS Production

ROS, mainly $\mathrm{H}_{2} \mathrm{O}_{2}$, are key immune defense products of photosynthesis $[84,108,109]$. In incompatible reactions, the accumulation of ROS is usually accompanied by a decrease in the photosynthesis rate because the inhibition of photosynthesis is conducive to ROS production and accumulation $[110,111]$. Moreover, pathogens invasion usually results in the downregulation of photosynthesis-related genes in the host even if the host is not sensitive to the pathogen $[65,112]$. These findings indicate that active downregulation of photosynthesis-related genes in incompatible reactions can induce the accumulation of ROS, driven by a decrease in the photosynthesis rate of the host. This idea is supported by numerous reports of changes in the expression of photosynthesis-related genes caused by interactions between wheat and its pathogens [113-115]. For example, RNA sequencing of wheat infected by Bgt revealed that ROS bursts are accompanied by a global downregulation of photosynthesis-related genes, including those encoding chlorophyll a/b-binding $(\mathrm{Cab})$ protein, ribulose bisphosphate carboxylase small chain (RbcS) protein, and ATP 
synthase, which parallel the decrease in the Pn [25]. Moreover, the significant decrease of chlorophyll fluorescence parameters ( $\mathrm{Fv}^{\prime} / \mathrm{Fm}^{\prime}, \mathrm{Fv} / \mathrm{Fm}$, ФPSII, ETR, qP) indicated that the photosynthetic electron transport chain of resistant wheat was blocked at the early stage of Bgt inoculation, which further supported that the decrease of photosynthesis was related to ROS production [25]. Transcriptome analysis of the susceptible cultivar Jingdong 8 and its resistant near-isogenic line also showed that the expression of a large number of photosynthesis-related proteins was inhibited at the early stage of inoculation with Bgt [116]. Additionally, the WKS1 protein encoded by stripe rust resistance gene Yr36 can phosphorylate an extrinsic member of PSII and reduce photosynthetic rate [71]. In addition, comparison of the gene expression profiles of resistant wheat after inoculation with Pst revealed that the systems that produce ROS and nitric oxide (NO) are enriched, and the expression of photosynthesis-related genes is also reduced during this period [114]. Taken together, these results support the idea that active downregulation of photosynthesisrelated genes disrupts photosynthesis as part of the incompatibility between parasitic fungi and wheat, which is associated with the activation of immune defenses.

Associations between F. graminearum infection and changes in photosynthesis in wheat have not been consistently recognized. Multiple gene expression profiles of FHB infection have suggested that the regulation of photosynthesis-related genes involving resistance to FHB is quite different from that involving stripe rust and powdery mildew. For example, analysis of the gene expression profile of QTL FhbL693b, which is a genomic region associated with FHB resistance, revealed that most of the differentially expressed genes detected in the region were related to photosynthesis, which indicates that photosynthesis may be involved in FHB resistance [74]. In addition, integrative transcriptome and hormone analysis indicated that SA and JA played a positive role in FHB resistance and that photosynthesis-related genes of the resistant variety Sumai 3 were downregulated at the early stage of inoculation [97]. Another study suggested that the ROS signaling pathways mediated by photosynthesis-related genes were not extremely important in FHB resistance because ROS-producing/scavenging systems were more active in the susceptible mutant than in the resistant variety Wangshuibai [94]. What is more, the transient susceptibility of the FHB-resistant line L693 and the inhibition of the ROS production system in Wangshuibai after inoculation indicated that photosynthesis-related genes did not directly induce the production of ROS to mitigate FHB resistance [74,94]. The development of resistance to FHB in wheat may depend on the activation of SAR by the SA and JA signaling pathways [97], which is also related to photosynthesis due to the synthesis of related hormones, mainly in chloroplasts [117].

\subsection{Photosynthesis-Related Genes Directly Regulate the Immune Defense}

In addition to producing ROS and regulating plant hormone levels to indirectly participate in plant immune defense, some proteins related to photosynthesis and genes related to photorespiration can directly regulate the defense response $[118,119]$. For example, the electron receptor protein ferredoxin-I (FD-I), which is involved in the photosynthetic process, is closely related to the production of ROS and the induction of the HR [120]. Inducing ferredoxin-like protein (AP1) expression in transgenic rice can increase resistance to Xanthomonas oryzae pv. oryzae [121]. In addition, compared with their wild-type counterparts, transgenic lines of Oncidium orchids are more resistant to soft rot disease when the coding sequence of ferredoxin-like protein (pflp) is transfected [122]. Moreover, transient overexpression of glycolate oxidase (GOX2), serine glyoxylate aminotransferase (SGT), and serine hydroxyl methyltransferase (SHMT1), which are involved in photorespiration in tobacco, increased the basic defense of transgenic lines against P. syringae [118]. On the other hand, interactions between pathogens and hosts revealed that many fungal effectors directly acted on chloroplasts and inhibited the immune response of plants by affecting the function of chloroplasts so that pathogens could successfully invade the host $[20,123,124]$. These clues suggest that several resistance genes may function together with photosynthesis to resist pathogen invasion. 
Changes in the expression of photosynthesis-related genes in wheat during pathogen invasion and photosynthetic changes caused by wheat resistance genes can help to compensate for the gaps in knowledge concerning the mechanisms underlying resistance genes in wheat. Lots of studies have indicated that the development of resistance through the action of several wheat resistance genes relies on photosynthesis and chloroplasts [125-127]. For instance, to improve wheat powdery mildew resistance, the transfection of several receptor protein kinase-encoding genes can improve resistance to powdery mildew by inducing ROS bursts $[90,126,127]$. A recent discovery showed that protein kinase receptors could phosphorylate NADPH oxidase to activate ROS in Arabidopsis thaliana, which implies that there is a link between resistance genes of receptor protein kinase and photosynthesis in wheat $[126,128,129]$. In addition, the wheat stripe rust resistance protein WKS1 directly phosphorylates thylakoid-associated ascorbate peroxidase (TAPX) in chloroplasts and decreases its peroxide-scavenging ability [130]. The WKS1 also acts directly in chloroplasts to participate in immune defense responses. Moreover, Li et al. [74] identified three photosynthesis-related genes involved in the development of FHB resistance via transcriptome analysis in the chromosomal region of the resistance QTL FhbL693B [74]. Together, these reports show that photosynthesis plays a key role in wheat resistance and that wheat resistance genes may regulate photosynthesis to mediate resistance against pathogen invasion.

\section{Summary and Future Efforts}

Similar to how temperature can be an indicator of disease for a doctor, photosynthesis could be an important indicator for a plant pathologist speculating about the results of interactions between hosts and pathogens. Changes in photosynthesis parameters in the early stage (usually within $24 \mathrm{~h}$ ) after pathogen infection could be an important causal agent contributing to the final resistance ability of plants, while changes in the late stage (usually $72 \mathrm{~h}$ ) after pathogen infection could be the result of the resistance response. In addition, wheat and its main fungal pathogens, including Bgt, Pst, and F. graminearum, constitute ideal plant-pathogen systems because of their different infection positions from a photosynthetic standpoint. By providing an overview of the relevant data, we aimed to develop a model to explain the putative mechanism through which photosynthesis is involved in the wheat resistance response (Figure 1). Infection with source pathogens could cause a decrease in the photosynthesis rate, while infection with sink pathogens could lead to an increase in the photosynthesis rate at local infection positions, but both infection types directly and indirectly result in a decrease in the photosynthesis rate in source organs, which may be associated with SAR. Usually, the larger the decreased amplitude is, the greater the tendency of incompatibility. This could be explained in view of the accumulation of ROS, especially $\mathrm{H}_{2} \mathrm{O}_{2}$, in source organs, which could be further used as signaling molecules to activate the HR and SAR. In our opinion, a clearer relationship or defined role of photosynthesis in interactions between hosts and pathogens could be determined by additional solid evidence in the future. 


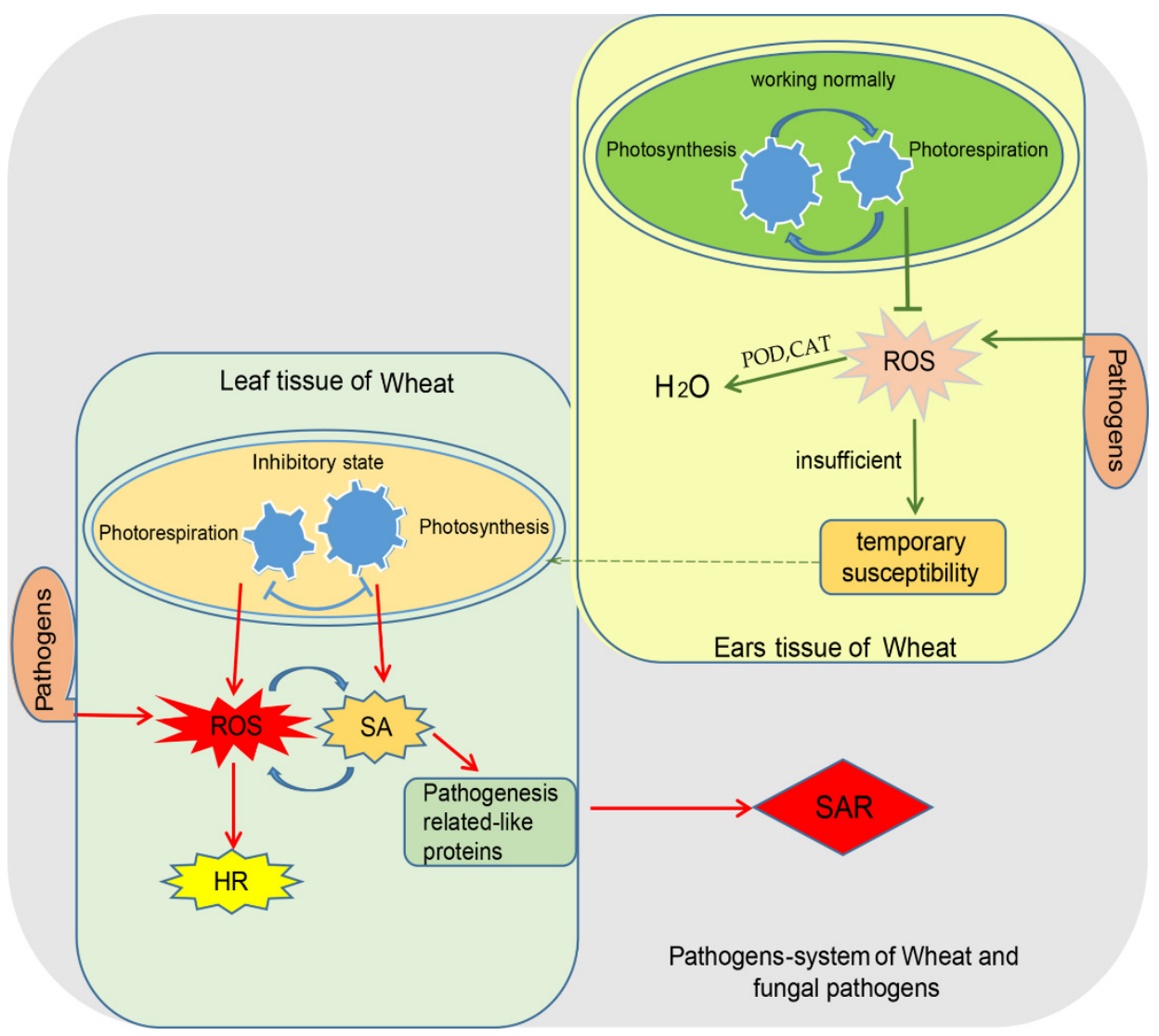

Figure 1. Hypothesized model of photosynthesis involving information concerning resistance to wheat source and sink diseases in the early stages of pathogen invasion.

Author Contributions: P.L. formulated the concept of the review; H.Y. wrote the draft; P.L. cowrote and edited the draft; H.Y. prepared the figures. All authors have read and agreed to the published version of the manuscript.

Funding: This research received no external funding.

Institutional Review Board Statement: Not applicable.

Informed Consent Statement: Not applicable.

Data Availability Statement: Not applicable.

Acknowledgments: We are grateful to the reviewers for their comments and suggestions on this review.

Conflicts of Interest: The authors declare that they have no conflicts of interest.

\section{References}

1. Smith, W.K.; Vogelmann, T.C.; Delucia, E.H.; Bell, D.T.; Shepherd, K.A. Leaf form and photosynthesis. BioScience 1997, 47, 785-793. [CrossRef]

2. Nilsen, E.T. Stem photosynthesis: Extent, patterns, and role in plant carbon economy. In Plant Stems; Gartner, B.L., Ed.; Academic Press: San Diego, CA, USA, 1995; pp. 223-240.

3. Cipollini, M.L.; Levey, D.J. Why some fruits are green when they are ripe: Carbon balance in fleshy fruits. Oecologia 1991, 88, 371-377. [CrossRef]

4. Kriedemann, P. The photosynthetic activity of the wheat ear. Ann. Bot. 1966, 30, 349-363. [CrossRef]

5. Göhre, V.; Jones, A.M.; Sklenář, J.; Robatzek, S.; Weber, A.P. Molecular crosstalk between PAMP-triggered immunity and photosynthesis. Mol. Plant Microbe Interact. 2012, 25, 1083-1092. [CrossRef] [PubMed]

6. Paul, M.J.; Foyer, C.H. Sink regulation of photosynthesis. J. Exp. Bot. 2001, 52, 1383-1400. [CrossRef]

7. Chaves, M.; Flexas, J.; Pinheiro, C. Photosynthesis under drought and salt stress: Regulation mechanisms from whole plant to cell. Ann. Bot. 2008, 103, 551-560. [CrossRef] [PubMed]

8. Hou, W.; Sun, A.H.; Chen, H.L.; Yang, F.S.; Pan, J.L.; Guan, M.Y. Effects of chilling and high temperatures on photosynthesis and chlorophyll fluorescence in leaves of watermelon seedlings. Biol. Plant. 2016, 60, 148-154. [CrossRef] 
9. Takahashi, S.; Badger, M.R. Photoprotection in plants: A new light on photosystem II damage. Trends Plant Sci. 2011, 16, 53-60. [CrossRef]

10. Quilliam, R.S.; Swarbrick, P.J.; Scholes, J.D.; Rolfe, S.A. Imaging photosynthesis in wounded leaves of Arabidopsis thaliana. J. Exp. Bot. 2005, 57, 55-69. [CrossRef]

11. Meyer, G.A.; Whitlow, T.H. Effects of leaf and sap feeding insects on photosynthetic rates of goldenrod. Oecologia 1992, 92, 480-489. [CrossRef]

12. Lu, Y.; Yao, J. Chloroplasts at the crossroad of photosynthesis, pathogen infection and plant defense. Int. J. Mol. Sci. 2018, 19, 3900. [CrossRef] [PubMed]

13. Tanveer, M.; Shahzad, B.; Sharma, A.; Khan, E.A. 24-Epibrassinolide application in plants: An implication for improving drought stress tolerance in plants. Plant Physiol. Biochem. 2019, 135, 295-303. [CrossRef] [PubMed]

14. Ristic, Z.; Bukovnik, U.; Momcilović, I.; Fu, J.; Vara Prasad, P.V. Heat-induced accumulation of chloroplast protein synthesis elongation factor, EF-Tu, in winter wheat. J. Plant Physiol. 2008, 165, 192-202. [CrossRef] [PubMed]

15. Zhang, Z.; Wu, P.; Zhang, W.; Yang, Z.; Liu, H.; Ahammed, G.J.; Cui, J. Calcium is involved in exogenous NO-induced enhancement of photosynthesis in cucumber (Cucumis sativus L.) seedlings under low temperature. Sci. Hortic. 2020, $261,108953$. [CrossRef]

16. Ku, S.; Edwards, G.E.; Tanner, C.B. Effects of light, carbon dioxide, and temperature on photosynthesis, oxygen inhibition of photosynthesis, and transpiration in Solanum tuberosum. Plant Physiol. 1977, 59, 868-872. [CrossRef]

17. Watanabe, T.; Kitagawa, H. Photosynthesis and translocation of assimilates in rice plants following phloem feeding by the planthopper Nilaparvata lugens (Homoptera: Delphacidae). J. Econ. Entomol. 2000, 93, 1192-1198. [CrossRef]

18. Lorenzini, G.; Guidi, L.; Nali, C.; Ciompi, S.; Soldatini, G.F. Photosynthetic response of tomato plants to vascular wilt diseases. Plant Sci. 1997, 124, 143-152. [CrossRef]

19. Costa Pinto, L.S.R.; Azevedo, J.L.; Pereira, J.O.; Carneiro Vieira, M.L.; Labate, C.A. Symptomless infection of banana and maize by endophytic fungi impairs photosynthetic efficiency. New Phytol. 2000, 147, 609-615. [CrossRef]

20. Kretschmer, M.; Damoo, D.; Djamei, A.; Kronstad, J. Chloroplasts and plant immunity: Where are the fungal effectors? Pathogens 2019, 9, 19. [CrossRef]

21. Walters, D.R.; Mcroberts, N.; Fitt, B.D. Are green islands red herrings? Significance of green islands in plant interactions with pathogens and pests. Biol. Rev. Camb. Philos. Soc. 2008, 83, 79-102. [CrossRef]

22. Swarbrick, P.J.; Schulze-Lefert, P.; Scholes, J.D. Metabolic consequences of susceptibility and resistance (race-specific and broad-spectrum) in barley leaves challenged with powdery mildew. Plant Cell Environ. 2006, 29, 1061-1076. [CrossRef]

23. Scharte, J.; Schön, H.; Weis, E. Photosynthesis and carbohydrate metabolism in tobacco leaves during an incompatible interaction with Phytophthora nicotianae. Plant Cell Environ. 2005, 28, 1421-1435. [CrossRef]

24. Chen, Y.E.; Cui, J.M.; Su, Y.Q.; Yuan, S.; Yuan, M.; Zhang, H.Y. Influence of stripe rust infection on the photosynthetic characteristics and antioxidant system of susceptible and resistant wheat cultivars at the adult plant stage. Front. Plant Sci. 2015, 6, 779. [CrossRef]

25. Hu, Y.; Zhong, S.; Zhang, M.; Liang, Y.; Gong, G.; Chang, X.; Tan, F.; Yang, H.; Qiu, X.; Luo, L.; et al. Potential role of photosynthesis in the regulation of reactive oxygen species and defence responses to Blumeria graminis f. sp. tritici in wheat. Int. J. Mol. Sci. 2020, 21, 5767. [CrossRef]

26. Bonfig, K.B.; Schreiber, U.; Gabler, A.; Roitsch, T.; Berger, S. Infection with virulent and avirulent P. syringae strains differentially affects photosynthesis and sink metabolism in Arabidopsis leaves. Planta 2006, 225, 1-12. [CrossRef] [PubMed]

27. Kumar, R.R.; Rai, R.D. Can wheat beat the heat: Understanding the mechanism of thermotolerance in wheat (Triticum aestivum L.). Cereal Res. Commun. 2014, 42,1-18. [CrossRef]

28. Duveiller, E.; Singh, R.P.; Nicol, J.M. The challenges of maintaining wheat productivity: Pests, diseases, and potential epidemics. Euphytica 2007, 157, 417-430. [CrossRef]

29. He, Z.; Lan, C.; Chen, X.; Zou, Y.; Zhuang, Q.; Xia, X. Progress and perspective in research of adult-plant resistance to stripe rust and powdery mildew in wheat. Sci. Agric. Sin. 2011, 44, 2193-2215.

30. Bai, G.; Shaner, G. Management and resistance in wheat and barley to fusarium head blight. Annu. Rev. Phytopathol. 2004, 42, 135-161. [CrossRef]

31. Conner, R.; Kuzyk, A.D.; Su, H. Impact of powdery mildew on the yield of soft white spring wheat cultivars. Can. J. Plant Sci. 2003, 83, 725-728. [CrossRef]

32. Yang, M.J.; Huang, K.Y.; Han, Q.D. Research progresses on wheat powdery mildew and its resistance. Mol. Plant Breed. 2016, 14, 1244-1254. [CrossRef]

33. Gao, H.; Niu, J.; Li, S. Impacts of wheat powdery mildew on grain yield \& quality and its prevention and control methods. Am. J. Agric. 2018, 6, 141-147. [CrossRef]

34. Wang, Z.-M.; Wei, A.-L.; Zheng, D.-M. Photosynthetic characteristics of non-leaf organs of winter wheat cultivars differing in ear type and their relationship with grain mass per ear. Photosynthetica 2001, 39, 239-244. [CrossRef]

35. Schwessinger, B. Fundamental wheat stripe rust research in the 21st century. New Phytol. 2017, 213, 1625-1631. [CrossRef] [PubMed]

36. Doodson, J.K.; Manners, J.G.; Myers, A. Some effects of yellow rust (Puccinia striiformis) on the growth and yield of a spring wheat. Ann. Bot. 1964, 28, 459-472. [CrossRef] 
37. Line, R.F. Stripe rust of wheat and barley in North America: A retrospective historical review. Annu. Rev. Phytopathol. 2002, 40, 75-118. [CrossRef]

38. Chen, W.; Wellings, C.; Chen, X.; Kang, Z.; Liu, T. Wheat stripe (yellow) rust caused by Puccinia striiformis f. sp. tritici. Mol. Plant Pathol. 2014, 15, 433-446. [CrossRef] [PubMed]

39. Leplat, J.; Friberg, H.; Abid, M.; Steinberg, C. Survival of Fusarium graminearum, the causal agent of Fusarium head blight. A review. Agron. Sustain. Dev. 2013, 33, 97-111. [CrossRef]

40. Parry, D.W.; Jenkinson, P.; Mcleod, L. Fusarium ear blight (SCAB) in small-grain cereals-A review. Plant Pathol. 2007, 44, 207-238. [CrossRef]

41. Cowger, C.; Sutton, A.L. The southeastern US Fusarium head blight epidemic of 2003. Plant Health Progress. 2005, 6, 4. [CrossRef]

42. Wegulo, S.N.; Baenziger, P.S.; Nopsa, J.H.; Bockus, W.W.; Hallen-Adams, H. Management of Fusarium head blight of wheat and barley. Crop Prot. 2015, 73, 100-107. [CrossRef]

43. Yang, S.; Li, X.; Chen, W.; Liu, T.; Zhong, S.; Ma, L.; Zhang, M.; Zhang, H.; Yu, D.; Luo, P. Wheat resistance to fusarium head blight is associated with changes in photosynthetic parameters. Plant Dis. 2016, 100, 847-852. [CrossRef]

44. Rosyara, U.R.; Subedi, S.; Duveiller, E.; Sharma, R.C. The effect of spot blotch and heat stress on variation of canopy temperature depression, chlorophyll fluorescence and chlorophyll content of hexaploid wheat genotypes. Euphytica 2010, 174, 377-390. [CrossRef]

45. Aboukhaddour, R.; Fetch, T.; Mccallum, B.D.; Harding, M.W.; Beres, B.L.; Graf, R.J. Wheat diseases on the prairies: A Canadian story. Plant Pathol. 2020, 69, 418-432. [CrossRef]

46. Xu, Q.; Tang, C.; Wang, X.; Sun, S.; Zhao, J.; Kang, Z.; Wang, X. An effector protein of the wheat stripe rust fungus targets chloroplasts and suppresses chloroplast function. Nat. Commun. 2019, 10, 5571. [CrossRef] [PubMed]

47. Spanic, V.; Viljevac Vuletic, M.; Drezner, G.; Zdunic, Z.; Horvat, D. Performance indices in wheat chlorophyll a fluorescence and protein quality influenced by FHB. Pathogens 2017, 6, 59. [CrossRef] [PubMed]

48. Kangasjärvi, S.; Tikkanen, M.; Durian, G.; Aro, E.M. Photosynthetic light reactions-An adjustable hub in basic production and plant immunity signaling. Plant Physiol. Biochem. 2014, 81, 128-134. [CrossRef]

49. Francesconi, S.; Balestra, G.M. The modulation of stomatal conductance and photosynthetic parameters is involved in Fusarium head blight resistance in wheat. PLoS ONE 2020, 15, e0235482. [CrossRef]

50. Walters, D.R.; Bingham, I.J. Influence of nutrition on disease development caused by fungal pathogens: Implications for plant disease control. Ann. Appl. Biol. 2007, 151,307-324. [CrossRef]

51. Serrago, R.A.; Carretero, R.; Bancal, M.O.; Miralles, D.J. Grain weight response to foliar diseases control in wheat (Triticum aestivum L.). Field Crop. Res. 2011, 120, 352-359. [CrossRef]

52. Singh, R.P.; Singh, P.K.; Rutkoski, J.; Hodson, D.P.; He, X.; Jørgensen, L.N.; Hovmøller, M.S.; Huerta-Espino, J. Disease impact on wheat yield potential and prospects of genetic control. Annu. Rev. Phytopathol. 2016, 54, 303-322. [CrossRef]

53. Niu, J.; Wang, H.; Hong, D. Advance in studies on molecular basis for wheat powdery mildew resistance. J. Henan Agric. Univ. 2006, 40, 678-682.

54. Hendrix, J.W.; Fuchs, E. Influence of fall stripe rust infection on tillering and yield of Wheat. Plant Dis. Rep. 1970, 54, 347-349.

55. Yang, F.P.; Yang, W.X.; Shang, X.W. A study on the effect of wheat stripe rust on wheat yield. J. Gansu Agric. Univ. 2008, 2, 51-55.

56. Wright, D.P.; Baldwin, B.C.; Shephard, M.C.; Scholes, J.D. Source-sink relationships in wheat leaves infected with powdery mildew. I. Alterations in carbohydrate metabolism. Physiol. Mol. Plant Pathol. 1995, 47, 237-253. [CrossRef]

57. Li, X.; Liu, T.-G.; Chen, W.; Zhong, S.; Zhang, H.; Tang, Z.; Chang, Z.; Wang, L.; Zhang, M.; Li, L.; et al. Wheat WCBP1 encodes a putative copper-binding protein involved in stripe rust resistance and inhibition of leaf senescence. BMC Plant Biol. 2015, 15, 239. [CrossRef] [PubMed]

58. Sutton, P.N.; Gilbert, M.J.; Williams, L.E.; Hall, J.L. Powdery mildew infection of wheat leaves changes host solute transport and invertase activity. Physiol. Plant. 2007, 129, 787-795. [CrossRef]

59. Chen, X.M. Epidemiology and control of stripe rust [Puccinia striiformis f. sp. tritici] on wheat. Can. J. Plant Pathol. 2005, 27, 314-337. [CrossRef]

60. Mccormick, A.J.; Cramer, M.D.; Watt, D.A. Changes in photosynthetic rates and gene expression of leaves during a source-sink perturbation in sugarcane. Ann. Bot. 2008, 101, 89-102. [CrossRef] [PubMed]

61. Bharath, P.; Gahir, S.; Raghavendra, A.S. Abscisic acid-induced stomatal closure: An important component of plant defense against abiotic and biotic stress. Front Plant Sci. 2021, 12, 324. [CrossRef]

62. Serrano, I.; Audran, C.; Rivas, S. Chloroplasts at work during plant innate immunity. J. Exp. Bot. 2016, 67, 3845-3854. [CrossRef] [PubMed]

63. Pieterse, C.M.; Leon-Reyes, A.; Van Der Ent, S.; Van Wees, S.C. Networking by small-molecule hormones in plant immunity. Nat. Chem. Biol. 2009, 5, 308-316. [CrossRef] [PubMed]

64. Bastiaans, L.; Kropff, M.J. Effects of leaf blast on photosynthesis of rice 2. canopy photosynthesis. Neth. J. Plant Pathol. 1993, 99, 205-217. [CrossRef]

65. Bilgin, D.D.; Zavala, J.A.; Zhu, J.; Clough, S.J.; Ort, D.R.; Delucia, E.H. Biotic stress globally downregulates photosynthesis genes. Plant Cell Environ. 2010, 33, 1597-1613. [CrossRef] [PubMed]

66. Sharma, A.; Vats, S.K.; Pati, P.K. Post-infectional dynamics of leaf spot disease in Withania somnifera. Ann Appl Biol. 2014, 165, 429-440. [CrossRef] 
67. Kangasjärvi, S.; Neukermans, J.; Li, S.; Aro, E.M.; Noctor, G. Photosynthesis, photorespiration, and light signalling in defence responses. J. Exp. Bot. 2012, 63, 1619-1636. [CrossRef]

68. Nogueira, A.F., Jr.; Ribeiro, R.V.; Appezzato-Da-Glória, B.; Soares, M.K.M.; Rasera, J.B.; Amorim, L. Phakopsora euvitis causes unusual damage to leaves and modifies carbohydrate metabolism in grapevine. Front. Plant Sci. 2017, 8, 1675. [CrossRef]

69. Ma, L.X.; Zhong, S.F.; Liu, N.; Chen, W.Q.; Liu, T.G.; Li, X.; Zhang, M.; Ren, Z.L.; Yang, J.Z.; Luo, P.G. Gene expression profile and physiological and biochemical characterization of hexaploid wheat inoculated with Blumeria graminis f. sp. tritici. Physiol. Mol. Plant Pathol. 2015, 90, 39-48. [CrossRef]

70. Luo, P.G.; Hu, X.Y.; Ren, Z.L.; Zhang, H.Y.; Shu, K.; Yang, Z.J. Allelic analysis of stripe rust resistance genes on wheat chromosome 2BS. Genome 2008, 51, 922-927. [CrossRef]

71. Wang, S.; Li, Q.-P.; Wang, J.; Yan, Y.; Zhang, G.-L.; Yan, Y.; Zhang, H.; Wu, J.; Chen, F.; Wang, X.; et al. YR36/WKS1-mediated phosphorylation of $\mathrm{PsbO}$, an extrinsic member of photosystem ii, inhibits photosynthesis and confers stripe rust resistance in wheat. Mol. Plant 2019, 12, 1639-1650. [CrossRef] [PubMed]

72. Bolton, M.D. Primary metabolism and plant defense-Fuel for the fire. Mol. Plant Microbe Interact. 2009, 22, 487-497. [CrossRef]

73. Qi, T.; Guo, J.; Liu, P.; He, F.; Wan, C.; Islam, M.A.; Tyler, B.M.; Kang, Z.; Guo, J. Stripe rust effector PstGSRE1 disrupts nuclear localization of ROS-promoting transcription factor TaLOL2 to defeat ROS-induced defense in wheat. Mol. Plant 2019, 12, 1624-1638. [CrossRef] [PubMed]

74. Li, X.; Zhong, S.; Chen, W.; Fatima, S.A.; Huang, Q.; Li, Q.; Tan, F.; Luo, P. Transcriptome analysis identifies a 140 kb region of chromosome 3B containing genes specific to fusarium head blight resistance in wheat. Int. J. Mol. Sci. 2018, 19, 852. [CrossRef] [PubMed]

75. Rychter, A.M. Antioxidants and reactive oxygen species in plants. Ann. Bot. 2006, 98, 1114. [CrossRef]

76. Sharma, P.; Jha, A.B.; Dubey, R.S.; Pessarakli, M. Reactive oxygen species, oxidative damage, and antioxidative defense mechanism in plants under stressful conditions. J. Bot. 2012, 2012, 217037. [CrossRef]

77. Apel, K.; Hirt, H. Reactive oxygen species: Metabolism, oxidative stress, and signal transduction. Annu. Rev. Plant Biol. 2004, 55, 373-399. [CrossRef] [PubMed]

78. Torres, M.A. ROS in biotic interactions. Physiol. Plant. 2010, 138, 414-429. [CrossRef] [PubMed]

79. Li, C.-Y.; Zhang, N.; Guan, B.; Zhou, Z.-Q.; Mei, F.-Z. Reactive oxygen species are involved in cell death in wheat roots against powdery mildew. J. Integr. Agric. 2019, 18, 1961-1970. [CrossRef]

80. Tsuda, K.; Katagiri, F. Comparing signaling mechanisms engaged in pattern-triggered and effector-triggered immunity. Curr. Opin. Plant Biol. 2010, 13, 459-465. [CrossRef] [PubMed]

81. Torres, M.A.; Jones, J.D.; Dangl, J.L. Reactive oxygen species signaling in response to pathogens. Plant Physiol. 2006, 141, 373-378. [CrossRef]

82. Qi, J.; Song, C.P.; Wang, B.; Zhou, J.; Kangasjärvi, J.; Zhu, J.K.; Gong, Z. Reactive oxygen species signaling and stomatal movement in plant responses to drought stress and pathogen attack. J. Integr. Plant Biol. 2018, 60, 805-826. [CrossRef]

83. Bowling, S.A.; Guo, A.; Cao, H.; Gordon, A.S.; Klessig, D.F.; Dong, X. A mutation in Arabidopsis that leads to constitutive expression of systemic acquired resistance. Plant Cell 1994, 6, 1845-1857. [CrossRef]

84. Shetty, N.P.; Jørgensen, H.J.L.; Jensen, J.D.; Collinge, D.B.; Shetty, H.S. Roles of reactive oxygen species in interactions between plants and pathogens. Eur. J. Plant Pathol. 2008, 121, 267-280. [CrossRef]

85. Wasternack, C. Jasmonates: An update on biosynthesis, signal transduction and action in plant stress response, growth and development. Ann. Bot. 2007, 100, 681-697. [CrossRef]

86. Overmyer, K.; Brosché, M.; Kangasjärvi, J. Reactive oxygen species and hormonal control of cell death. Trends Plant Sci. 2003, 8, 335-342. [CrossRef]

87. Shah, J. The salicylic acid loop in plant defense. Curr. Opin. Plant Biol. 2003, 6, 365-371. [CrossRef]

88. Asada, K. Production and scavenging of reactive oxygen species in chloroplasts and their functions. Plant Physiol. 2006, 141, 391-396. [CrossRef] [PubMed]

89. Zurbriggen, M.D.; Carrillo, N.; Hajirezaei, M.R. ROS signaling in the hypersensitive response: When, where and what for? Plant Signal. Behav. 2010, 5, 393-396. [CrossRef] [PubMed]

90. Wang, Z.; Cheng, J.; Fan, A.; Zhao, J.; Yu, Z.; Li, Y.; Zhang, H.; Xiao, J.; Muhammad, F.; Wang, H.; et al. LecRK-V, an L-type lectin receptor kinase in Haynaldia villosa, plays positive role in resistance to wheat powdery mildew. Plant Biotechnol. J. 2018, 16, 50-62. [CrossRef]

91. Kumar, A.; Karre, S.; Dhokane, D.; Kage, U.; Hukkeri, S.; Kushalappa, A.C. Real-time quantitative PCR based method for the quantification of fungal biomass to discriminate quantitative resistance in barley and wheat genotypes to fusarium head blight. $J$. Cereal Sci. 2015, 64, 16-22. [CrossRef]

92. Mesterhazy, A. Types and components of resistance to Fusarium head blight of wheat. Plant Breed. 1995, 114, 377-386. [CrossRef]

93. Ding, L.; Xu, H.; Yi, H.; Yang, L.; Kong, Z.; Zhang, L.; Xue, S.; Jia, H.; Ma, Z. Resistance to hemi-biotrophic F. graminearum infection is associated with coordinated and ordered expression of diverse defense signaling pathways. PLoS ONE 2011, 6, e19008. [CrossRef]

94. Xiao, J.; Jin, X.; Jia, X.; Wang, H.; Cao, A.; Zhao, W.; Pei, H.; Xue, Z.; He, L.; Chen, Q.; et al. Transcriptome-based discovery of pathways and genes related to resistance against Fusarium head blight in wheat landrace Wangshuibai. BMC Genom. 2013, 14, 197. [CrossRef] 
95. Walter, S.; Nicholson, P.; Doohan, F.M. Action and reaction of host and pathogen during Fusarium head blight disease. New Phytol. 2010, 185, 54-66. [CrossRef] [PubMed]

96. Ye, J.; Zhang, Q.-Q.; Lizhu, E.; Dai, W.; Xu, M.-L. The GT factor ZmGT-3b mediates growth-defense tradeoff by regulating photosynthesis and defense response. bioRxiv 2021. [CrossRef]

97. Wang, L.; Li, Q.; Liu, Z.; Surendra, A.; Pan, Y.; Li, Y.; Zaharia, L.I.; Ouellet, T.; Fobert, P.R. Integrated transcriptome and hormone profiling highlight the role of multiple phytohormone pathways in wheat resistance against fusarium head blight. PLoS ONE 2018, 13, e0207036. [CrossRef] [PubMed]

98. Li, Q.; Gao, C.; Xu, K.; Jiang, Y.; Niu, J.; Yin, G.; Wang, C. Transcriptome-based analysis of resistance mechanism to black point caused by Bipolaris sorokiniana in wheat. Sci. Rep. 2021, 11, 1-13. [CrossRef]

99. Ghosh, S.; Kanwar, P.; Jha, G. Alterations in rice chloroplast integrity, photosynthesis and metabolome associated with pathogenesis of Rhizoctonia solani. Sci. Rep. 2017, 7, 1-12. [CrossRef]

100. Cohen, S.P.; Leach, J.E. Abiotic and biotic stresses induce a core transcriptome response in rice. Sci. Rep. 2019, 9, 1-11. [CrossRef]

101. Doke, N.; Miura, Y.; Sanchez, L.M.; Park, H.J.; Noritake, T.; Yoshioka, H.; Kawakita, K. The oxidative burst protects plants against pathogen attack: Mechanism and role as an emergency signal for plant bio-defence-A review. Gene 1996, 179, 45-51. [CrossRef]

102. Zhu, J.; Li, M.; Clough, S. Similarities and differences in global gene expression profiles between herbicide-and pathogen-induced PSII inhibition. J. Plant Biochem. Physiol. 2015, 3, 1-9. [CrossRef]

103. Quan, L.J.; Zhang, B.; Shi, W.W.; Li, H.Y. Hydrogen peroxide in plants: A versatile molecule of the reactive oxygen species network. J. Integr. Plant Biol. 2008, 50, 2-18. [CrossRef]

104. Xing, F.; Li, Z.; Sun, A.; Xing, D. Reactive oxygen species promote chloroplast dysfunction and salicylic acid accumulation in fumonisin B1-induced cell death. FEBS Lett. 2013, 587, 2164-2172. [CrossRef]

105. Belkadhi, A.; De Haro, A.; Soengas, P.; Obregon, S.; Cartea, M.E.; Chaibi, W.; Djebali, W. Salicylic acid increases tolerance to oxidative stress induced by hydrogen peroxide accumulation in leaves of cadmium-exposed flax (Linum usitatissimum L.). J. Plant Interact. 2014, 9, 647-654. [CrossRef]

106. Müller, M.; Munné-Bosch, S. Hormonal impact on photosynthesis and photoprotection in plants. Plant Physiol. 2021, 185, 1500-1522. [CrossRef]

107. Derksen, H.; Rampitsch, C.; Daayf, F. Signaling cross-talk in plant disease resistance. Plant Sci. 2013, 207, 79-87. [CrossRef] [PubMed]

108. Kuźniak, E.; Kopczewski, T. The chloroplast reactive oxygen species-redox system in plant immunity and disease. Front. Plant Sci. 2020, 11, 572686. [CrossRef] [PubMed]

109. Gechev, T.S.; Van Breusegem, F.; Stone, J.M.; Denev, I.; Laloi, C. Reactive oxygen species as signals that modulate plant stress responses and programmed cell death. Bioessays 2006, 28, 1091-1101. [CrossRef] [PubMed]

110. Dinakar, C.; Abhaypratap, V.; Yearla, S.R.; Raghavendra, A.S.; Padmasree, K. Importance of ROS and antioxidant system during the beneficial interactions of mitochondrial metabolism with photosynthetic carbon assimilation. Planta 2010, 231, 461-474 [CrossRef]

111. Su, J.; Yang, L.; Zhu, Q.; Wu, H.; He, Y.; Liu, Y.; Xu, J.; Jiang, D.; Zhang, S. Active photosynthetic inhibition mediated by MPK3/MPK6 is critical to effector-triggered immunity. PLoS Biol. 2018, 16, e2004122. [CrossRef]

112. Rojas, C.M.; Senthil-Kumar, M.; Tzin, V.; Mysore, K.S. Regulation of primary plant metabolism during plant-pathogen interactions and its contribution to plant defense. Front. Plant Sci. 2014, 5, 17. [CrossRef] [PubMed]

113. Zhang, H.; Yang, Y.; Wang, C.; Liu, M.; Li, H.; Fu, Y.; Wang, Y.; Nie, Y.; Liu, X.; Ji, W. Large-scale transcriptome comparison reveals distinct gene activations in wheat responding to stripe rust and powdery mildew. BMC Genom. 2014, 15, 898. [CrossRef]

114. Hao, Y.; Wang, T.; Wang, K.; Wang, X.; Fu, Y.; Huang, L.; Kang, Z. Transcriptome analysis provides insights into the mechanisms underlying wheat plant resistance to stripe rust at the adult plant stage. PLoS ONE 2016, 11, e0150717. [CrossRef]

115. Wang, Y.; Huang, L.; Luo, W.; Jin, Y.; Gong, F.; He, J.; Liu, D.; Zheng, Y.; Wu, B. Transcriptome analysis provides insights into the mechanisms underlying wheat cultivar Shumai126 responding to stripe rust. Gene 2021, 768, 145290. [CrossRef]

116. Xin, M.; Wang, X.; Peng, H.; Yao, Y.; Xie, C.; Han, Y.; Ni, Z.; Sun, Q. Transcriptome comparison of susceptible and resistant wheat in response to powdery mildew infection. Genom. Proteom. Bioinform. 2012, 10, 94-106. [CrossRef]

117. Mullet, J.E. Dynamic regulation of chloroplast transcription. Plant Physiol. 1993, 103, 309-313. [CrossRef]

118. Sørhagen, K.; Laxa, M.; Peterhänsel, C.; Reumann, S. The emerging role of photorespiration and non-photorespiratory peroxisomal metabolism in pathogen defence. Plant Biol. 2013, 15, 723-736. [CrossRef]

119. Rodríguez-Herva, J.J.; González-Melendi, P.; Cuartas-Lanza, R.; Antúnez-Lamas, M.; Río-Alvarez, I.; Li, Z.; López-Torrejón, G.; Díaz, I.; Del Pozo, J.C.; Chakravarthy, S.; et al. A bacterial cysteine protease effector protein interferes with photosynthesis to suppress plant innate immune responses. Cell. Microbiol. 2012, 14, 669-681. [CrossRef]

120. Huang, H.E.; Ger, M.J.; Chen, C.Y.; Pandey, A.K.; Yip, M.K.; Chou, H.W.; Feng, T.Y. Disease resistance to bacterial pathogens affected by the amount of ferredoxin-I protein in plants. Mol. Plant Pathol. 2007, 8, 129-137. [CrossRef] [PubMed]

121. Tang, K.; Sun, X.; Hu, Q.; Wu, A.; Lin, C.; Lin, H.; Twyman, R.M.; Christou, P.; Feng, T. Transgenic rice plants expressing the ferredoxin-like protein (AP1) from sweet pepper show enhanced resistance to Xanthomonas oryzae pv. oryzae. Plant Sci. 2001, 160, 1035-1042. [CrossRef] 
122. Liau, C.H.; Lu, J.C.; Prasad, V.; Hsiao, H.H.; You, S.J.; Lee, J.T.; Yang, N.S.; Huang, H.E.; Feng, T.Y.; Chen, W.H.; et al. The sweet pepper ferredoxin-like protein (pflp) conferred resistance against soft rot disease in Oncidium orchid. Transgenic Res. 2003, 12, 329-336. [CrossRef]

123. Mansfield, J.; Genin, S.; Magori, S.; Citovsky, V.; Sriariyanum, M.; Ronald, P.; Dow, M.; Verdier, V.; Beer, S.V.; Machado, M.A.; et al. Top 10 plant pathogenic bacteria in molecular plant pathology. Mol. Plant Pathol. 2012, 13, 614-629. [CrossRef]

124. Jelenska, J.; Van Hal, J.A.; Greenberg, J.T. Pseudomonas syringae hijacks plant stress chaperone machinery for virulence. Proc. Natl. Acad. Sci. USA 2010, 107, 13177-13182. [CrossRef] [PubMed]

125. Feng, H.; Wang, X.; Zhang, Q.; Fu, Y.; Feng, C.; Wang, B.; Huang, L.; Kang, Z. Monodehydroascorbate reductase gene, regulated by the wheat PN-2013 miRNA, contributes to adult wheat plant resistance to stripe rust through ROS metabolism. Biochim. Biophys. Acta 2014, 1839, 1-12. [CrossRef] [PubMed]

126. Xia, T.; Yang, Y.; Zheng, H.; Han, X.; Jin, H.; Xiong, Z.; Qian, W.; Xia, L.; Ji, X.; Li, G.; et al. Efficient expression and function of a receptor-like kinase in wheat powdery mildew defence require an intron-located MYB binding site. Plant Biotechnol. J. 2021, 19, 897-909. [CrossRef] [PubMed]

127. Chen, T.; Xiao, J.; Xu, J.; Wan, W.; Qin, B.; Cao, A.; Chen, W.; Xing, L.; Du, C.; Gao, X.; et al. Two members of TaRLK family confer powdery mildew resistance in common wheat. BMC Plant Biol. 2016, 16, 27. [CrossRef]

128. Kimura, S.; Hunter, K.; Vaahtera, L.; Tran, H.C.; Citterico, M.; Vaattovaara, A.; Rokka, A.; Stolze, S.C.; Harzen, A.; Meißner, L.; et al. CRK2 and C-terminal phosphorylation of NADPH oxidase RBOHD regulate reactive oxygen species production in arabidopsis. Plant Cell 2020, 32, 1063-1080. [CrossRef]

129. Kimura, S.; Waszczak, C.; Hunter, K.; Wrzaczek, M. Bound by fate: The role of reactive oxygen species in receptor-like kinase signaling. Plant Cell 2017, 29, 638-654. [CrossRef] [PubMed]

130. Gou, J.Y.; Li, K.; Wu, K.; Wang, X.; Lin, H.; Cantu, D.; Uauy, C.; Dobon-Alonso, A.; Midorikawa, T.; Inoue, K.; et al. Wheat stripe rust resistance protein WKS1 reduces the ability of the thylakoid-associated ascorbate peroxidase to detoxify reactive oxygen species. Plant Cell 2015, 27, 1755-1770. [CrossRef] 